\title{
The Role of Price in Deciding to Purchase Ready-to-Drink Tea
}

\author{
Arissetyanto Nugroho \\ Universitas Mercu Buana Jakarta \\ arissoehardjo@mercubuana.ac.id
}

\begin{abstract}
The purpose of this research is to test the factors that influence the decision to purchase The Pucuk Harum tea. There are three variables tested: brand image, price and product quality. The questionnaire was delivered to 100 @ pucukharumid consumers and bootstrapped for a 500 data sample. The findings support that all factors, i.e. brand image, price and product quality, significantly influence the decision to purchase The Pucuk Harum. The most important factor is the price, and the factor that had the least influence is image. Smart PLS Simultaneous Equation Modelling was conducted to measure the indirect relationship between fourpaths within the model. The results show that the strongest path is the process of prices that affect the image through the product quality. The price is also an antecedent factor that mostly influences the purchase decision through other variables within the model.
\end{abstract}

Keywords: decision to purchase, price, product quality, brand image

\section{INTRODUCTION}

Soft drink sales in 2016 increased 8\% compared to the prior year, and the increase was influenced by ready-to-drink tea, which hada market share of 10 to $13 \%$ (Euromonitor, 2018). The growth of this market share shows the potential of ready-to-drink tea. Prior to 2017, there were2.117 million litresof ready-to-drink tea consumed in the Indonesian market (Euromonitor, 2018). Sales of soft drinks continue to experience growth relevant to the characteristics of Indonesians who live in urban areas. The patterns and lifestyles of those who live in the city emphasise speed and mobility, along with a variety of activities. Those in the city leave for work in the morning, arrive at the office, perform various activities, experience traffic congestion on the way home and then interact with their family members before finally sleeping.

These busy activities require ready-to-eat food and drinks. This is the reason why the demand for soft drinks has been growing steadily because they can accommodate the needs of the urban communities for practical products, and they are also hygienic and suit the public's tastes. Specifically, in Indonesia, people are accustomed to enjoying sweet tea or fresh tea since childhood. Furthermore, consumers enjoying ready-to-drink tea is a growing trend. Tea offered in hygienic plastic packaging convinces consumers that the tea is clean, tasty and offered at affordable prices.

The The Pucuk Harum brand is not the pioneer in the Indonesian market. The Pucuk Harum launched in 2011 and claimed to be produced from selected tea leaves. In the last three years, The Pucuk Harum has been able to compete with some of the brands that had entered into the market much earlier, such as Teh Kotak, The Gelas and Frestea.

In 2017, The Gelas had a 40.5\% market share, while The Pucuk had 11.1\%, The Sosro had $9.6 \%$ and Frestea had 7.4\% (Euromonitor, 2018). Sosro is the only brand that 
has declined in market share. The Pucuk Harumh as gained the market's confidence that its products are relevant to consumers' needs.

The competition in the Indonesian market is fierce, as there are The Gelas, TehPucuk Harum, Sosro, Frestea and dozens of other brands. The Pucuk Harum is the second ranked ready-to-drink tea an dearneda higher market share than Sosro (the former market leader). This is an outstanding achievement from The Pucuk Harum; therefore, this research will focus on testing the factors that influence the decision to purchase The Pucuk Harum.

Previous research on food has stated that consumers consider brands, prices and product information, and these factors positively influence the purchase decision (Ares et al., 2010; Ferrarezi et al., 2013; Sirijanya Kuawiriyapan, 2014; Wang \&Yu, 2015). Nevertheless, the research on ready-to-drink tea in Indonesia is scarce. Therefore, the price, brand image, product quality and decision-to-purchase variables will be tested within this research, and a questionnaire will be developed based on are view of the relevant literature.

\section{LITERATURE REVIEW}

Price. Non-store shopping would be most appealing to price-oriented individuals (Korgaonkar, 1984). The cost to obtain the brand or product compared to the benefits received will affect the consumer's satisfaction. If the consumer feels there is a greater benefit than cost, the consumer will feel satisfaction. Because itis an important determinant in creating customer satisfaction, price becomes a focal variable within this research (Ferrarezi et al., 2013).

Comparing the price of products or other brands on the market is necessary within competitive markets. If there is another product that has the same benefits but acheaper price, consumers will likely choose these cheaper products. If a company provides greater benefits than those provided by the cheaper competition, the consumer's decision will be uncertain. Because of the complexity of pricing and the quality of the product, price becomes an important factor in the evaluation of consumer satisfaction (Amornpetchkul, 2016; Sihite, et al., 2016).

The price function consists of four costs:1) the cost to produce the product, 2) the market price, 3) the combination of the market price and the cost to produce and 4) the general market price. Thus, considering these four costs can simplify pricing. In the context of this research, the price of ready-to-drink tea depends on the price of the market competitors. A minimum price reflects the cost of production, and the pricing should not be too far below the market price because it will reduce the company's long-term profits (Amornpetchkul, 2016).

The price represents the monetary value a buyer must give to a seller as part of a purchase agreement; therefore, a customer's price perception is closely related to the perception of quality, value and other beliefs (Nagle \&Holden, 2002). Recent research on food preference shows that the purchase intent for ready-to-drink orange juice and nectar was strongly influenced by the product's price, brand and information, which contributed to positive purchase intent (Ferrarezi et al., 2013). Therefore, the hypotheses constructed and tested in this study are as follows:

$\mathrm{H}_{1}$ : There is a positive effect of price towardsproduct quality.

$\mathrm{H}_{2}$ : There is a positive effect of price towardsthe brand image.

$\mathrm{H}_{3}$ : There is a positive effect of price towardsthepurchase decision. 
Product Quality. The features and benefits of a product or service are meant to satisfy consumers' needs; there fore, these features and benefits determine the quality of the product or service. If the expectations are higher than the realised quality of the product or service, consumers experience dissatisfaction. However, if the desired expectations are lower than the realised benefits, then consumers experience satisfaction. The fulfilment of needs is critical for consumers (Kelley et al., 2015). Consumers will always review the service quality compared to the fulfilment of their needs (Veale \& Quester, 2009).

People believe tea has health benefits; therefore, tea is widely consumed (Del Rio et al., 2010). Tea is also less expensive compared to other drinks, being cheaper than everything but water (Hazarika, 2013). Because tea can maintain health, increase stamina and act as a depressant, many generations and social statuses consume tea. Drinking tea is also a culture for many people in the world, and two-thirds of the world population drinks tea (Kim et al., 2011).

Consumers determine quality by evaluating their experiences with products or services (Erenkol \& Duygun, 2010). Whenever they interact with advertising, sales promotions or other attributes of a product or brand, consumers will gradually establish a reference concerning the product or brand. During the purchasing process, references to the quality of a product will build a mechanism to compare the product within the market. Product quality is crucial for consumer consideration. Consumers consider brands, low prices and product information. Ares et al. (2010) stated that these factors positively influence the decision to purchase.

The results of other studies show that the perceived value of a brand is the quality considered by the consumers. The higher the quality, the higher values perceived by consumers (Jahanzeb et al., 2013). This concept makes every brand develop a higher value than the costs incurred; thus, consumers will feel lucky because the benefits are greater than the costs.

Quality and brand value are related to consumer satisfaction (Cronin \& Hult, 2000). Chen and Chang (2012) confirmed that positive values affect consumer confidence and influence the purchase decision. Senthilnathan and Tharmi (2012) showed that consumer satisfaction, as influenced by the quality of the reference brand value, will affect consumer trust and the decision to purchase the product. Product quality is crucial for consumer consideration (Ares et al., 2010). Therefore, the hypotheses constructed and tested in this study are as follows:

$\mathrm{H}_{4}: \quad$ There is a positive effect of product quality towards brand image.

$\mathrm{H}_{5}$ : There is a positive effect of price towardsthe decision to purchase.

Brand Image. Brand image is the perception in the mind of consumers when considering a product or service (Aaker, 1996). If a person has a deep understanding and a high memory for a product or service, they will have a positive behaviour, and strong brands canconvince consumers to purchase products or services (Erdem et al., 2002; Huang et al., 2014). Brand image is a symbolic meaning associated with the features of the brand,and that image becomes the brand's identity when compared to other competitors. The brand image is associated with the psychological meaning in a person's mind, and that image is presented for the targeted consumer (Cretu \& Brodie, 2007; Nugroho \& Sihite, 2017).

Brand reference has a certain quality level. There are at least four groups of reference levels:1)basic knowledge of the brand, 2) the quality of the reference brand, 3) 
the preferred association of the brand and 4) the loyalty of a reference brand. The reference value is about loyalty and to the likelihood to repurchase the product or service. The higher the quality of the reference, the more the reference will enhance loyalty (Aaker, 1991).

Another definition forvalue or brand equity is a set of things that are owned by a brand/product, suchas brand names, symbols or logos, that increase or decrease the value of the brand in the consumer's mind (Chen, 2010). Value or brand equity is what influences satisfaction and the consumer's purchasing decision regarding the various options within the market.

The quality or value of the brand could be measured by comparing the benefits and costs to consume the brand. However, if the brand's quality is unique, the value cannot be replaced by other competitors (Aaker, 1996). If consumers remember the brand image association, they are likely to consume the selected product or service (Lafferty et al., 2002; Ng et al., 2014). Therefore, the hypothesis constructed and tested in this study is as follows:

$\mathrm{H}_{6}$ : There is a positive effect of brand image towardsthe decision to purchase.

Decision to Purchase. Euromonitor (2018) predicted that the beverage industry for readyto-drink tea in Indonesia, particularly in the plastic bottle segment, will grow better than the ready-to-drink tea in plastic cups. The competition between ready-to-drink tea inside plastic bottles comparedto that in plastic cups will be more intense.

Euromonitor (2018) stated that ready-to-drink tea in plastic cups isfacing challenges from competitors inplastic bottles, such as The Pucuk Harum, because the price of The Pucuk Harum is affordable, they are performing aggressive promotion and the products are availablein a variety of distribution channels. Therefore, it is interesting to hypothesise the factors that influence the purchasing decisions of The Pucuk Harum.

Tea consumption is also growing more consistent compared with carbonated beverages. Carbonated beverage consumption continues to fall as more and more people become aware of their health consequences. The international market for ready-to-drink tea also continues to increase (Cho et al., 2005).

Busy people purchase ready-to-drink tea since they demand fast delivery (Shinozaki \&Harada, 2014). Ready-to-drink tea facilitates the consumption of tea several times a day. Therefore, the bottled package could be consumed to satisfy the consumer's thirst several times. Ready-to-drink tea allows tea to be purchased by consumers who performa variety of activities. The bottled tea can be brought to the office, in the car oron public transport, or it can even be stored in the refrigerator and enjoyed when consumers return home.

The numerous reasons to purchase ready-to-drink tea makes the competition within the industry fierce, and players improve the market by creating innovations, such as making a variety of tea flavours for different consumer categories (Lee \& Liao, 2009). Consumers purchase ready-to-drink tea with caffeine that can have effects similar to drinking coffee (Hewlett \&Wadsworth, 2012), increasing focus and improving mental awareness (Smith, 2002; Su, 2007). Some people simply enjoy tea for the flavour ( $\mathrm{Su}$, 2007). In addition, other attributes of ready-to-drink tea is the brand reputation, the price and quantity relevancy, how the tea relieves thirst, the advertising and the quality (Lee \& Liao, 2009). Therefore, the model developed in this research is shown in Figure 1: 


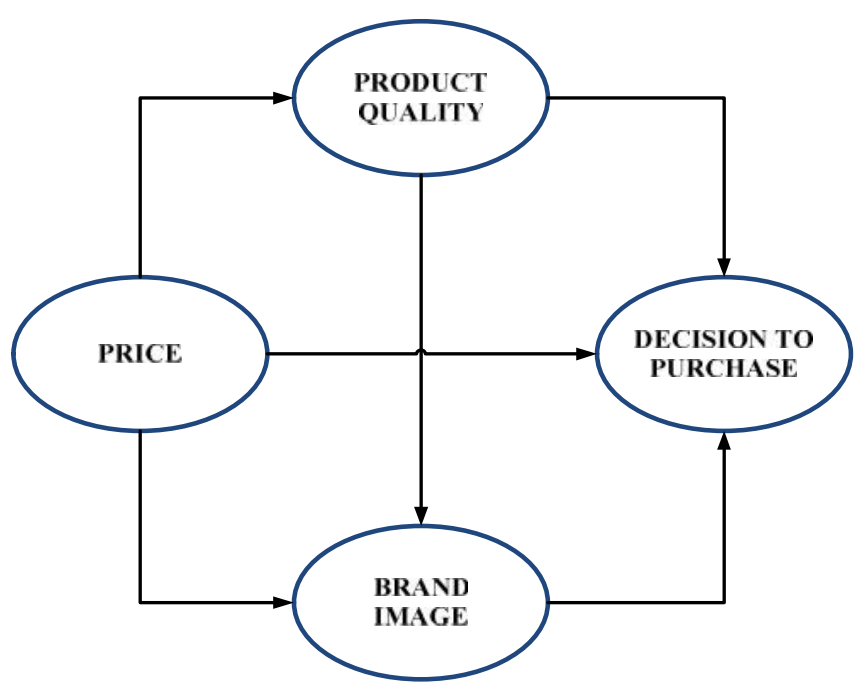

Figure 1. Decision to Purchase Model

\section{METHOD}

This study's purpose is to test the hypotheses regarding price, brand image and product quality variables towards the decision to purchase within the context of The Pucuk Harum. Data is collected using a structured questionnaire sent to 100 consumers of The Pucuk Harum, and screening questions related to the criteria of the respondents were included. The Pucuk Harum targets students; therefore, the questionnaires were distributed to the students of Universitas Mercu Buana as the sample. Furthermore, the data collection was conducted during October 2018, and this is cross-sectional data.

Based on the data collected, the majority of respondents were women $(61.0 \%)$, and most respondents were between the ages of $21-24$ (82.0\% of total respondents). All respondents were students of the Faculty of Economics \& Business Universitas Mercu Buana, and most of them were studying Management (65\%). Table 1 provides an overview of the respondents' characteristics.

Table 1. Characteristics of Respondents

\begin{tabular}{llcc}
\hline \multicolumn{1}{c}{ Characteristics } & \multicolumn{1}{c}{ Classification } & Number & Percentage (\%) \\
\hline Gender & Male & 39 & 39.0 \\
& Female & 61 & 61.0 \\
Age & 17-20 years & 15 & 15.0 \\
& 21-24 years & 82 & 82.0 \\
& $>25$ years & 3 & 3.0 \\
Occupation & Student/college student & 100 & 100.0 \\
Study Programme & Management & 65 & 65.0 \\
& Accounting & 35 & 35.0
\end{tabular}

Note: $n=100$

Source: Own processing 
This research tests the hypotheses within the model. The 100 sample respondents were The Pucuk Harum consumers. The variables and indicators were developed from the existing literature on price, product quality, brand images and decision to purchase in the context of ready-to-drink products. These indicators were previously investigated, and theyare the brand image variable from Sirijanya Kuawiriyapan (2014), the price variable from Sirijanya Kuawiriyapan (2014)and Wang and Yu (2015), the product quality from Sirijanya Kuawiriyapan (2014) and Wang and Yu (2015) and the decision to purchase from Ferrarezi et al. (2013).

There are four indicators for brand image, four indicators for price, seven indicators for product quality and four indicators for the decision to purchase, fora total of 19 indicators. Table 2 presents the questionnaire developed with the additional screening questions and demographic questions.

Table 2. Variable Operationalisation

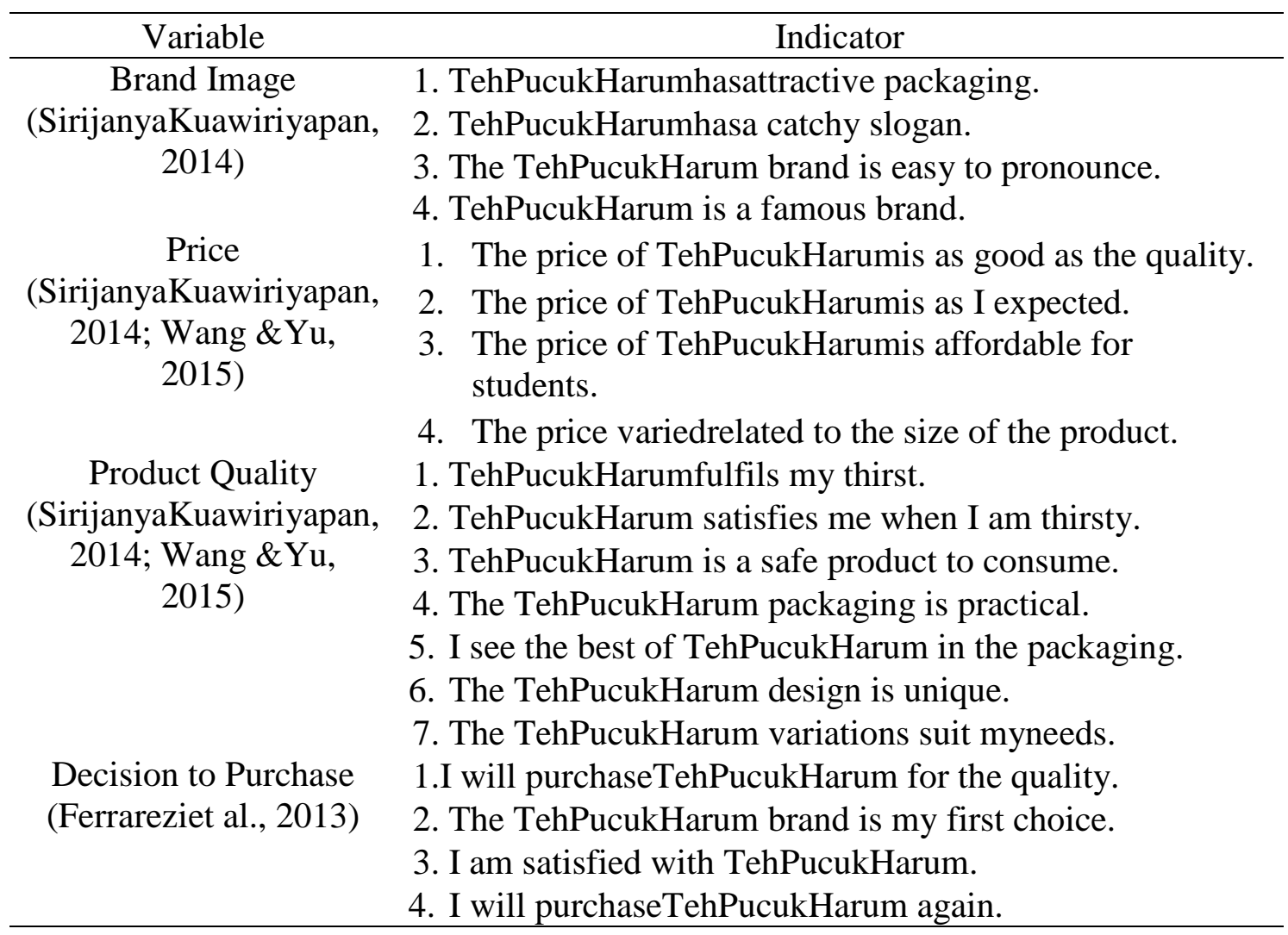

After the questionnaire was delivered to the respondents, the survey results were further tested using Structural Equation Modelling (SEM). This process is part of causal research, with the ultimate goal being to confirm the relationship betweenthe variables examined (Istijanto, 2005). The confirmatory analysis was based on the theory that built the variable operationalisation.

The Smart PLS software makes it easy for a researcher to obtain the highest degree of certainty of findings. Smart PLS has a bootstrap option, and a bootstrap for 500 samples was utilised for this research. This method gives the consequences for measuring the hypothesis, and the hypothesis is accepted or rejected depending on the measuredLLCI 
(Lower Lower Confidence Interval) and ULCI (Upper Lower Confidence Interval). If the results of the coefficients are in the range between LLCI and ULCI, then the hypothesis is accepted; however, if the coefficient is below the LLCI or above the ULCI, then the hypothesis is rejected. Bootstrapping is an option to generate sub-samples from the original samples, and this enhancement will strengthen the value of the coefficient (Bollen \& Stine, 1993; Efron \& Tibshirani, 1994; Stine, 1989).

Smart PLS allows for seeing the connections between the model's independent and dependent variables. The result of this output would further enrich the analysis and define when the independent variable is related to adependent variable.

SEM is conducted as a statistical model to explain the relationship between several variables within a model (Anderson \& Swaminathan, 2011; Assaker et al., 2013). SEM tested the structure of the association in a series of equations, and these equations originated from the total connections between the constructs comprised of independent and dependent variables (Hair et al., 2013). Within this research, the SEM method used was Partial Least Square (PLS), and the PLS applied a relaxed assumption compared with covariance-based SEM.

PLS is different from the other SEM analysis models. The data with a minimum of $30>$ samples can be used in this analysis; therefore, it should not be a multivariate Gaussian. PLS can also be used to check theory plausibility and to define the connection between latent variables. PLS is able to estimate a large and complex model with latent variables and hundreds of thousands of indicators (Falk \&Miller, 1992).PLS-SEM is an extremelyuseful, powerful analysis tool because the results are robust. Critics have said that PLS results have a significant bias on the basis of how the simulation is conducted; however, the bias in PLS- SEM is extremely low (Hair et al., 2011). Hair et al. (2013) said that the PLS-SEM method isthe silver bullet, a square with accurate results.

The PLS-SEM method usesalinearity assumption to gain a meaningful interpretation of the regression coefficient results (Darlington, 1990). Through linear regression, one can use the data to test the linearity assumption. The regression analysis method in this study defined $\mathrm{Y}$ as a result and $\mathrm{X}$ as a predictor (Hayes, 2013). The predictor variables, which are price, brand image and product quality, predict the dependent variables' decision to purchase. Analysis starts with a test of validity and reliability (Hair et al., 1998). Measuring the level of $\mathrm{R}^{2}$ determines how the dependent variables are explained by the predictor variables. Furthermore, the value of $\mathrm{f}^{2}$ means there is an indirect effect from the independent variables towards the dependent variable.

\section{RESULTS AND DISCUSSION}

This studyteststhe decision to purchase model. The variable reliability shows that all variables have values above 0.5 ; thus, they are reliable. The highest reliability exists in the product quality variable, whichhas seven indicators, followed bythe price variable and then the image variable, which is the smallestwith only fourindicators (Table 3).

Furthermore, SmartPLS confirmed the relationships between these paths towards the decision to purchase variable. The results showed that all the variables, which are brand image, price and product quality, significantly affect the decision to purchase. SmartPLS enables the output to show the most influential coefficient towards the decision to purchase. 
Table 3. Cronbach Alpha Reliability

\begin{tabular}{lll}
\hline Variable & Cronbach's & Remarks \\
\hline Brand Image & 0.630 & Reliable \\
Price & 0.863 & Reliable \\
Product Quality & 0.907 & Reliable \\
Decision to Purchase & 0.800 & Reliable \\
\hline
\end{tabular}

The most influential variable is price (0.639), while the least influential variable is image (0.26; Table 4).

Table 4. Decision to Purchase

\begin{tabular}{|c|c|c|c|c|c|c|c|}
\hline $\begin{array}{l}\text { Outcome: } \\
\text { Decision to } \\
\text { Purchase } \\
\text { Model Summary }\end{array}$ & $\mathrm{R}^{2}$ & & & & & & \\
\hline & 0.495 & & & & & & \\
\hline Model & Coeff & Bias & LLCI & ULCI & se & $\mathrm{t}$ & $\mathrm{p}$ \\
\hline Brand Image & 0.26 & 0 & 0.07 & 0.446 & 0.091 & 2.844 & 0.005 \\
\hline Price & 0.44 & 0.004 & 0.258 & 0.615 & 0.09 & 4.844 & 0 \\
\hline Product Quality & 0.155 & -0.005 & -0.039 & 0.38 & 0.106 & 1.505 & 0.133 \\
\hline Effect Size & $\mathrm{F} 2$ & & & & & & \\
\hline Brand Image & 0.26 & & & & & & \\
\hline Price & 0.639 & & & & & & \\
\hline Product Quality & 0.288 & & & & & & \\
\hline
\end{tabular}

The brand image variable has two independent variables, namely price and product quality. The results of the data analysis showed that price and product quality significantly affect brand image. The interesting thing is the coefficient of the price is a minus, and this means that anincrease in price will give a negative effect on the image. The highest coefficient is the product quality at 0.513 , while the price influence is 0.351 (Table 5).

Table 5. Brand Image

\begin{tabular}{|c|c|c|c|c|c|c|c|}
\hline $\begin{array}{l}\text { Outcome: Brand } \\
\text { Image } \\
\text { Model Summary }\end{array}$ & $\mathrm{R}^{2}$ & & & & & & \\
\hline & 0.24 & & & & & & \\
\hline Model & Coeff & Bias & LLCI & ULCI & $\mathrm{Se}$ & $\mathrm{T}$ & $\mathrm{p}$ \\
\hline Price & -0.007 & 0.008 & -0.389 & 0.199 & 0.14 & 0.113 & 0.91 \\
\hline Product Quality & 0.513 & 0.012 & 0.235 & 0.687 & 0.111 & 4.52 & 0 \\
\hline Effect Size & $\mathrm{F} 2$ & & & & & & \\
\hline Price & 0.351 & & & & & & \\
\hline Product Quality & 0.513 & & & & & & \\
\hline
\end{tabular}


The findings of this research show that product quality affects brand image. Good quality products will increase the value of the brand image more than expensive pricing. The relationship between the price and the brand image has a negative coefficient, meaningarise in price will cause a decline in brand image.

The last model is product quality, which is the dependent variable in the model that is affected by the independent variable price. Price significantly affects product quality, and because there is only one independent variable in the model that affects product quality, the value of its influence ishigh (0.696). The findings of this research show that price affects product quality. Within this model, price has a central role in the decision to purchase (Table 6).

Table 6. Product Quality

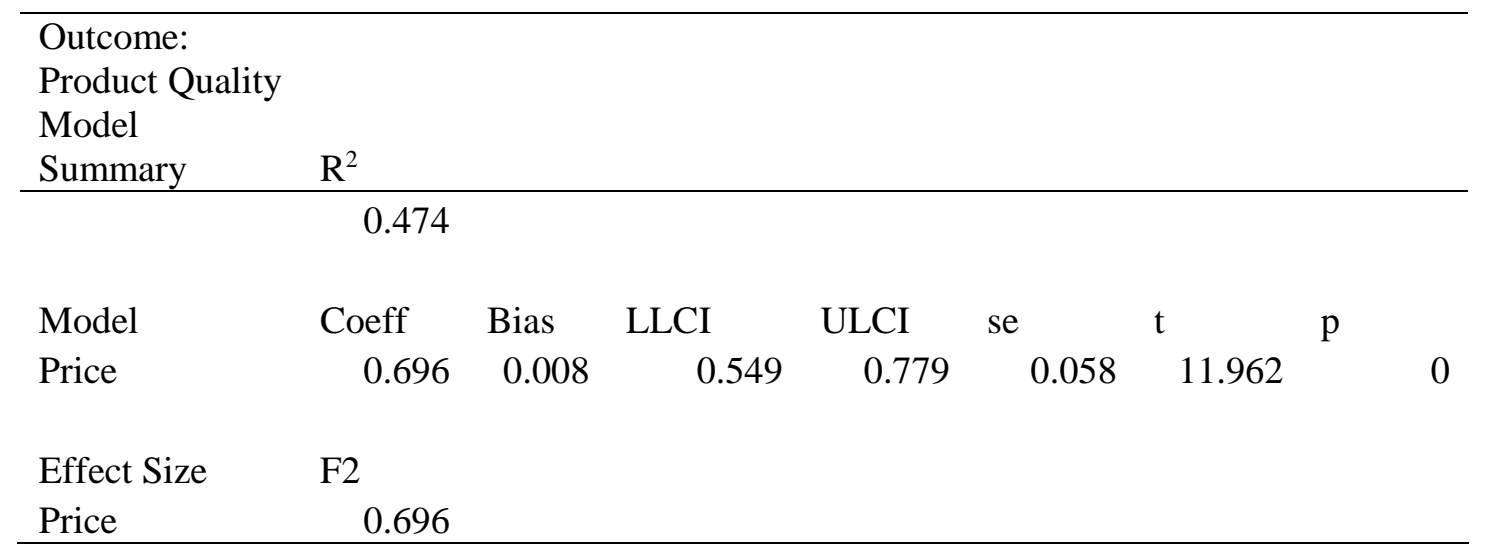

Smart PLS allows for examining the effect of specific and total indirect effects. If considering the total effect, one can interpret that the price is indeed influencing the decision to purchase and product quality when compared to the other variables. Price affects the decision to purchase by 0.635 and affects product quality by 0.688 . However, only brand image has the power to influence the decision to purchase (Table 7).

If considering what variables have a large total effect, one can see that the product's quality has a 0.501 effect on image. This means that prices do have a large role in influencing product quality and that product quality is a strong factor or mediating variable in influencing the intention to buy The Pucuk Harum (Table 6). The effect of product quality towards brand image is 0.501 . This means that prices indeed have a significant role in affecting the quality of the product, and the product quality is astrong factor or mediating variable in influencing the decision to purchase The Pucuk Harum (Table 7 and Figure 2).

Table 7. Total Effects

\begin{tabular}{|c|c|c|c|c|}
\hline \multicolumn{5}{|l|}{ Total Effects } \\
\hline & Brand Image & Price & Decision to Purchase & Product Quality \\
\hline Brand Image & & & 0.26 & \\
\hline Price & 0.329 & & 0.632 & 0.688 \\
\hline Decision to Purchase & & & & \\
\hline Product Quality & 0.501 & & 0.29 & \\
\hline
\end{tabular}




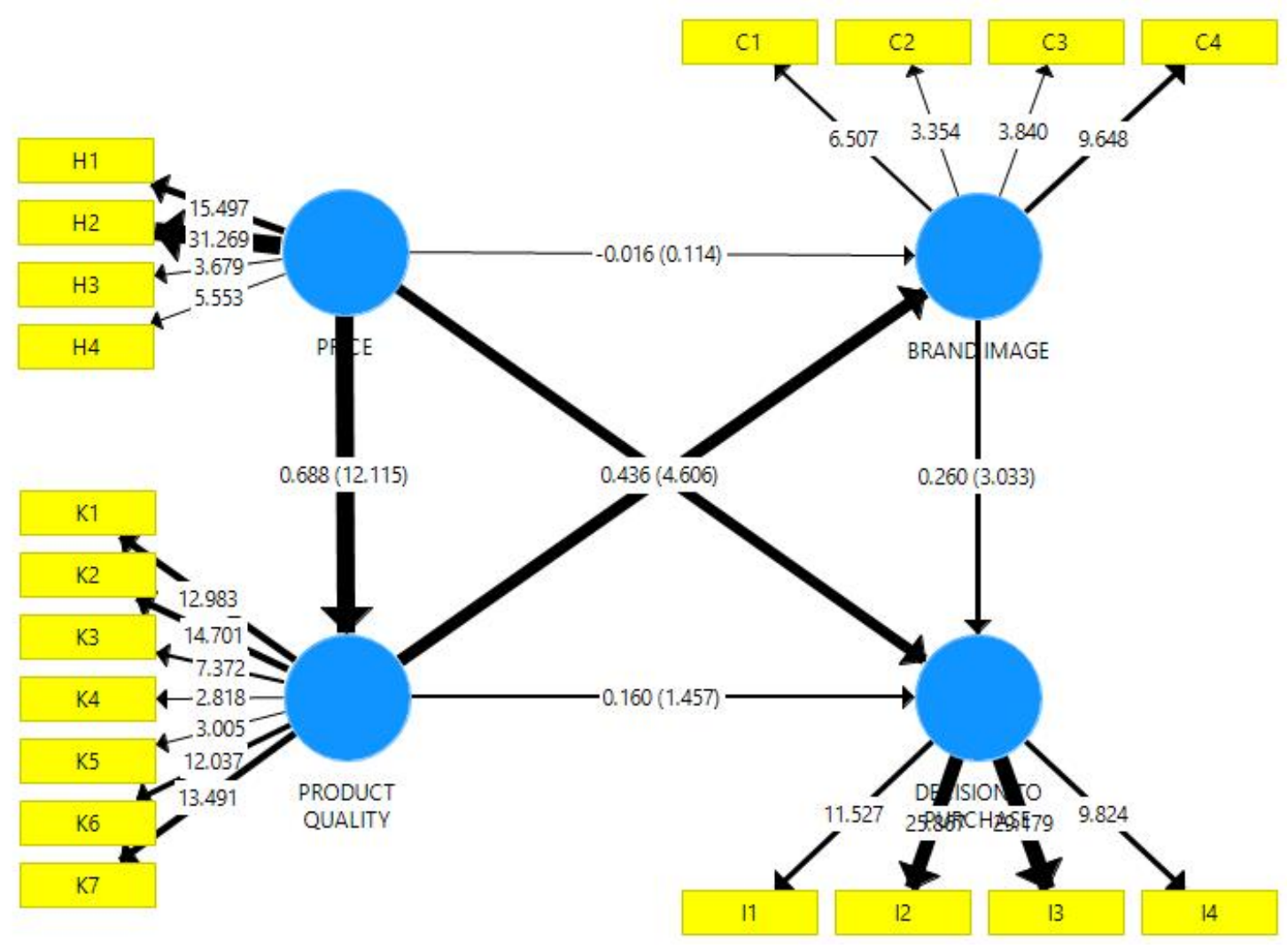

Figure 2. Inner andOuter Effects

Given the total effect,exploring the indirect effects is required. The most significant indirect effect is on the path of prices $\rightarrow$ product quality $\rightarrow$ image of 0.345 . Thus, this is a significant path in the decision to purchase TehPucukHarum. The other indirect pathsare far smaller (Table 8).

Table 8. Total Indirect Effects

\begin{tabular}{|c|c|c|c|c|c|}
\hline Total Indirect Effects & Brand Image & Price & $\begin{array}{l}\text { Decision to } \\
\text { Purchase }\end{array}$ & & $\begin{array}{l}\text { Product } \\
\text { Quality }\end{array}$ \\
\hline Brand Image & \multirow{3}{*}{\multicolumn{2}{|c|}{0.345}} & \multirow{2}{*}{\multicolumn{3}{|c|}{0.195}} \\
\hline $\begin{array}{l}\text { Price } \\
\text { Decision to Purchase }\end{array}$ & & & & & \\
\hline Product Quality & & & & 0.13 & \\
\hline
\end{tabular}

Table 9. Specific Indirect Effects

\begin{tabular}{lr}
\hline Specific Indirect Effects & \\
\hline Price $\rightarrow$ Product Quality $\rightarrow$ Brand Image & 0.345 \\
Price $\rightarrow$ Brand Image $\rightarrow$ Decision to Purchase & -0.004 \\
Price $\rightarrow$ Product Quality $\rightarrow$ Brand Image $\rightarrow$ Decision to Purchase & 0.09 \\
Price $\rightarrow$ Product Quality $\rightarrow$ Decision to Purchase & 0.11 \\
\hline
\end{tabular}


The second greatest path is the price $\rightarrow$ product quality $\rightarrow$ decision to purchase of0.11. This value means the price and product quality is indeed a central variable in the model of the decision to purchase. This is also relevant for the model's reliability, which considers price and product quality as the most reliable variables compared to the other two variables (Table 9).

Finally, one can also see how the model is sufficient to describe the phenomenon. The R2 value is a representation of adequacy, and the results show that the R2 value is greatest in the model for the decision to buy, with a value of 0.495 . The product quality can be explained by 0.474 through the price independent variable. Compared to the previous model of a larger buying decision, it consists of three independent variables, while product quality is only influenced by one variable, namely price. The results of this study indicate that prices have a central role in the purchasing decision model of The Pucuk Harum.

\section{CONCLUSION}

In the introduction, Euromonitor (2018) stated that the competition between two categories of ready-to-drink tea in Indonesia is intense. The market segmentation of readyto-drink tea in plastic cups is price sensitive compared to the plastic bottled ready-to-drink tea that targeted the middle and upper classes. The ready-to-drink tea in the plastic cup will still dominate the market in Indonesia. Although consumers in this market are sensitive to price, the market share that demands ready-to-drink tea in plastic cups is still more dominant. Therefore, the competition between the two categories is becoming interesting to evaluate (Euromonitor, 2018). Based on the results of this research, the price-sensitive segment isthe plastic bottled ready-to-drink tea.

The sales volume of ready-to-drink tea declined $2.1 \%$ in 2017 due to the targeted community's declining/stagnant income. This research confirmed that the price-sensitive segment of ready-to-drink tea in plastic bottlestargets college and high school students.

Thus, the target consumer of the ready-to-drink tea in plastic bottles will increase within the next few years, as the higher-income population will grow. The demand for ready-to-drink tea in plastic bottles will also increase, as it provides practicality fo rconsumers who donot immediately want to finish their drink (Euromonitor, 2018). There fore, this study recommends that The Pucuk Harum should avoid price increases due to the price-sensitive consumers in the student segment.

This research's findings contribute various characteristics of the market segment for ready-to-drink teas in plastic bottles. These diverse variations provide managerial implications if there are price increases associated with The Pucuk Harum plastic bottles, andthe company should consider a promotion to relax the price increase. The number of potential students is extremely large; there fore, The Pucuk Harum cannot ignore this market segment, which can be termed 'The Bottom of the Ready-to-Drink Tea Pyramid in Indonesia'.

Students also a rational group, and they realise that ready-to-drink tea in plastic bottles has better product quality. The additional benefits and the cost to consume The Pucuk Harum is reasonable. Thus, product quality and price significantly influence the decision to purchase. Furthermore, research must be conducted to test different segment groups to determine the price sensitivity difference between targeted segments. Finally, 
this research has provided interesting findings regarding the segment atthe bottom of ready-to-drink teapyramid in Indonesia.

\section{REFERENCES}

Aaker, D. A. (1996). "Measuring brand equity across products and markets". California management review, 38(3), 102-120.

Aaker, D. A., \& Equity, M. B. (1991). The Free Press. New York, 206.

Amornpetchkul, T. B. (2016). "Ichitan Group And The Price Wa in Thailand's Ready To Drink Tea Market”. Journal of the International Academy for Case Studies, 22(3).

Anderson, R. E., \& Swaminathan, S. (2011). "Customer Satisfaction And Loyalty In EMarkets: A PLS Path Modelling Approach". Journal of Marketing Theory and Practice, 19(2), 221-234. Retrieved from http://search.proquest.com/docview/857424464? accountid=17242.

Assaker, G., Hallak, R., O'Connor, P., \&Vinzi, V. E. (2013). "Partial Least Squares Path Modelling (PLSPM): A New Direction for Research in Tourism and Hospitality". Journal of Travel and Tourism Research (Online), 13(12), 158-179. Retrieved from http://search.proquest.com/docview/1508765275?accountid=17242

Ares, G., Giménez, A., \&Deliza, R. (2010). "Influence of three non-sensory factors on consumer choice of functional yogurts over regular ones". Food Quality and Preference, 21(4), 361-367.

Bollen, K. A., \& Stine, R. A. (1993). Bootstrapping goodness-of-fit measures in structural equation models. Sage Focus Editions, 154, 111-111.

Campbell, C., Pitt, L., Parent, M., \& Berthon, P. (2011). “Tracking Back-Talk in Consumer-Generated Advertising". Journal of advertising research, 51(1), 224238.

Chen, Y. S. (2010). "The drivers of green brand equity: Green brand image, green satisfaction, and green trust". Journal of Business ethics, 93(2), 307-319.

Chen, Y. S., \& Chang, C. H. (2012). "Enhance green purchase intentions: The roles of green perceived value, green perceived risk, and green trust". Management Decision, 50(3), 502-520.

Cho, H.Y.,Chung, S.J., J., H.S., \& Kim,K.O (2005.”Effect Of Sensory Characteriwics and Non Sensory Facors on Consumer Liking of Various Cannel TeaProducts", Journal of food Science, 70(8).

Cretu, A. E., \& Brodie, R. J. (2007). "The influence of brand image and company reputation where manufacturers market to small firms: A customer value perspective". Industrial Marketing Management, 36(2), 230-240.

Cronin Jr, J. J., \& Brady, M. K. Hult, 0. TM (2000). "Assessing the effects of quality, value, and customer satisfaction on consumer behavioral intentions in service environments". Journal of Retailing, 76(2), 93-98.

Darlington, R. B. (1990). Regression and linear models, McGraw-Hill New York. data analysis.

Del Rio, D., Calani, L., Scazzina, F., Jechiu, L., Cordero, C., \&Brighenti, F. (2010). Bioavailability of catechins from ready-to-drink tea. Nutrition, 26(5), 528-533.

Efron, B., \&Tibshirani, R. J. (1994). An introduction to the bootstrap: CRC press.

Erdem, T., Swait, J., \& Louviere, J. (2002). "The impact of brand credibility on consumer price sensitivity". International journal of Research in Marketing, 19(1), 1-19. 
Erenkol, A. D. and Duygun, A.(2010)."Customerse perceived brand equity and a research on the customers of Bellona which is a Turkish furniture brand". The Journal of American Academy of Business, 16(1), 34-42.

Euromonitor. (2018). RTD Tea in Indonesia Analysis. Euromonitor International

Falk, R. F., \& Miller, N. B. (1992). A primer for soft modeling: University of Akron Press.

Ferrarezi, A., Minim, V. P., dos Santos, K. M., \& Monteiro, M. (2013). "Consumer attitude towards purchasing intent for ready to drink orange juice and nectar". Nutrition \& Food Science, 43(4), 304-312.

Hair, J. F., Ringle, C. M., \&Sarstedt, M. (2011). "PLS-SEM: Indeed A Silver Bullet". Journal of Marketing Theory and Practice, 19(2), 139-151. Retrieved from http://search.proquest.com/docview/857424245? accountid=17242

Hayes, A. F. (2013). Introduction to mediation, moderation, and conditional process analysis: A regression-based approach: Guilford Press.

Hazarika, K. (2013). "Tea supply chain; Its impact on garden development: A study on selected tea gardens of Assam, India”. International Journal of Marketing and Technology, 3(3), 80.

Hewlett, P., \& Wadsworth, E. (2012). "Tea, coffee and associated lifestyle factors". British Food Journal, 114(3), 416-427.

Huang, Y. C., Yang, M., \& Wang, Y. C. (2014). "Effects of green brand on green purchase intention". Marketing Intelligence \& Planning, 32(3), 250-268.

Istijanto, M. M. (2005). Aplikasipraktisrisetpemasaran. GramediaPustaka Utama.

Jingxia, L. V., \&Zhaodan, S. H. E. N. (2012). A Comparative Study Of Tea Customs/Une Etude Comparative Des Clients De The. Cross-Cultural Communication, 8(2), 128.

Jahanzeb, S., Fatima, T., \& Mohsin Butt, M. (2013). "How service quality influences brand equity: The dual mediating role of perceived value and corporate credibility". International Journal of Bank Marketing, 31(2), 126-141.

Kelley, K., Hyde, J., \&Bruwer, J. (2015). "US wine consumer preferences for bottle characteristics, back label extrinsic cues and wine composition: A conjoint analysis". Asia Pacific Journal of Marketing and Logistics, 27(4), 516-534.

Kim, Y., Welt, B. A., \& Talcott, S. T. (2011). "The impact of packaging materials on the antioxidant phytochemical stability of aqueous infusions of green tea (Camellia sinensis) and yaupon holly (Ilex vomitoria) during cold storage". Journal of agricultural and food chemistry, 59(9), 4676-4683.

Kuawiriyapan, S. (2014). "Factors affecting ready-to-drink murrahmilkconsumption in bangkok metropolitan”. International Journal of Arts \& Sciences, 7(4), 61.

Korgaonkar, P.K. (1984), "Consumer shopping orientations, non-store retailers, and consumers' patronage intentions: a multivariate investigation", Journal of the Academy of Marketing Science, Vol. 12, pp. 11-22.

Lafferty, B. A., Goldsmith, R. E., \& Newell, S. J. (2002). "The dual credibility model: The influence of corporate and endorser credibility on attitudes and purchase intentions". Journal of Marketing Theory and Practice, 10(3), 1-11.

Lee, C. W., \& Liao, C. S. (2009). "The effects of consumer preferences and perceptions of Chinese tea beverages on brand positioning strategies". British Food Journal, 111(1), 80-96.

Nagle, T.T. and Holden, R.K. (2002), The Strategy and Tactics of Pricing: A Guide to Profitable Decision Making, PrenticeHall, Englewood Cliffs, NJ 
Ng, P. F., Butt, M. M., Khong, K. W., \& Ong, F. S. (2014). “Antecedents of green brand equity: an integrated approach". Journal of Business Ethics, 121(2), 203-215.

Nugroho, A., \&Sihite, J. (2017). Brand Extension in the Marketspace: An Exploratory Study from Air Asia. Journal of Economic \& Management Perspectives, 11(3).

Senthilnathan, S., \&Tharmi, U. (2012). "The Relationship of Brand Equity to Purchase Intention". The IUP Journal of Marketing Management, 6(2), 7-26.

Shinozaki, Y., \& Harada, Y. (2014). "Rapid detection of bacteria in green tea using a novel pretreatment method in a bioluminescence assay". Journal of food protection, 77(6), 941-947.

Sihite, J., Harun, T. W., \&Nugroho, A. (2016). The Low Cost Airline Consumer Price Sensitivity: An Investigation on the Mediating Role of Promotion and Trust in Brand. International Research Journal of Business Studies, 7(3).

Smith, A. (2002). "Effects of caffeine on human behavior". Food and chemical toxicology, 40(9), 1243-1255.

Stine, R. (1989). "An introduction to bootstrap methods examples and ideas". Sociological Methods \& Research, 18(2-3), 243-291.

Su, S. W. (2007). "Tea or coffee: A study of the beverage choice pattern and its affecting factors at teatime in Kaohsiung, Taiwan". Asia Pacific Management Review, 12(4), 245-257.

Subramanian, R., Kumar, C. S., \& Sharma, P. (2014). "Membrane clarification of tea extracts". Critical reviews in food science and nutrition, 54(9), 1151-1157.

Veale, R., \& Quester, P. (2009). "Tasting quality: the roles of intrinsic and extrinsic cues". Asia Pacific Journal of Marketing and Logistics, 21(1), 195-207.

Wang, E. S.-T., \& Yu, J.-R. (2016). "Means-end chain approach for exploring the motivation of ready-to-drink tea consumers". Asia Pacific Journal of Marketing and Logistics, 28(3), 384-395.

Wijanto, S. H. (2008). Structural Equation Modelingdengan LISREL 8.8: Konsep dan Tutorial.

$\mathrm{Wu}$, C., \& Wu, S. I. (1998). "A proposed method for the development of marketing mix of the tea drink market”. Asia Pacific Journal of Marketing and Logistics, 10(1), 321. 